\title{
Ecological Zonation of Phytoplankton and Biomass Based on Bio-Optical Parameters off Baja California during Three Summer Seasons
}

\author{
Sánchez-Pérez Elvia Denisse ${ }^{1,2 *}$, Millán-Núñez Eduardo ${ }^{1}$ \\ ${ }^{1}$ Department of Marine Ecology, Centro de Investigación Científica y de Educación Superior de Ensenada, \\ Ensenada, México \\ ${ }^{2}$ Department of Plankton and Marine Ecology, CONACyT-Instituto Politécnico Nacional-Centro Interdisciplinario de Ciencias \\ Marinas, La Paz, México \\ Email: *ocdenisse@gmail.com
}

How to cite this paper: Elvia Denisse, S.-P. and Eduardo, M.-N. (2019) Ecological Zonation of Phytoplankton and Biomass Based on Bio-Optical Parameters off Baja California during Three Summer Seasons. Open Journal of Marine Science, 9, 121-136. https://doi.org/10.4236/ojms.2019.93010

Received: April 27, 2019

Accepted: July 19, 2019

Published: July 22, 2019

Copyright (c) 2019 by author(s) and Scientific Research Publishing Inc. This work is licensed under the Creative Commons Attribution International License (CC BY 4.0).

http://creativecommons.org/licenses/by/4.0/

\begin{abstract}
An ecological zonation of phytoplankton was determined from its normalized spectral absorption shape $\left(a_{p h} n\right)$ during the summers of 2001-02-03 off the west coast of Baja California. In the first two seasons, the highest abundances of the main taxonomic groups of phytoplankton were detected towards the coastal stations, but for 2003, diatoms showed higher abundances towards the oceanic region. The ecological provinces $(\mathrm{Pv})$ were the footprint of the zonation in the structure of the phytoplankton community; likewise, it was observed that the spectral shape was independent of the chlorophyll-a $\left(\mathrm{mg} \cdot \mathrm{m}^{-3}\right)$. The effect of coastal upwelling south of Vizcaíno Bay favored the increase of phytoplankton cells. However, the composition of the community decreased in cells abundance and diversity due to the influence of the phenomenon called El Niño "débil" reported to the south of the California Current for the years 2002-03.
\end{abstract}

\section{Keywords}

Ecological Zonation, Phytoplankton, Bio-Optics, El Niño Débil

\section{Introduction}

The structure of the phytoplankton community and its primary production are a fundamental part of the marine pelagic ecosystem since it contributes a quarter of the total carbon fixation rate with $35-50 \mathrm{Gt} \mathrm{C} \mathrm{Y}^{-1}$ with an important role in the global carbon cycle $\mathrm{CO}_{2}$ via the biological carbon pump [1] [2]. Such assertions ponder the importance to know the phytoplankton taxonomic composition 
and its spatial-temporal variability at a regional and mesoscale level, as well as the biogeochemical processes and physiology of phytoplankton in the oceans, including the transfer of energy to deep layers and gas exchange with the atmosphere [3] [4]. For this reason, the scientific community has increased studies and implemented methodologies on phytoplankton ecology and its short and medium term variability, in order to determine a better understanding of primary productivity and changes in the biological ecosystem in relation to anomalous events such as "El Niño-La Niña" [5]. During El Niño events, the temperature tends to increase associated with a decrease in the concentration of nutrients, chlorophyll $a$ and primary productivity [6], the thermocline sinks and the presence of warm waters with few nutrients, on the contrary in La Niña events, where the surface temperature decreases, the thermocline rises and the concentration of nutrients and primary productivity levels increase [7]. The physical and biological oceanographic conditions in the CC off Baja California (BC) during 2001 period have been widely characterized by [8] [9] [10], where these authors emphasize the presence of upwelling that favoring the increased of phytoplankton. Authors such as [10] [11] [12] used climate indices such as the ENSO (El Niño-Southern Oscillation), MEI (Multivariate El Niño) [13], and PDO (Pacific Decadal Oscillation) [14] to determine oceanographic differences that occurred between the summers 2002-03 in relation to the 2001 to the south of the CC off Baja California. Currently, the high variability of photosynthetic pigments allows us to detect changes in phytoplankton biomass, as well as the physiological state of cells through bio-optical parameters such as light absorption coefficient by phytoplankton $\left(a_{p h}\right)$. Actually, these changes in the communities can be detected using satellite data, and thus allow to improve the bio-optical algorithms already established in relation to the color ocean [15] [16]. Recent studies have shown a high variability of the $a_{p h}$ in relation to the concentration and composition of pigments, remarking in a certain flat shape of the spectral curve so-called packet effect, caused by large cells by decreasing the efficiency of light absorption [11] [17] [18] [19]. Likewise, the non-linear relationship between the $a_{p h}$ vs Chl-a concentration, which makes it difficult to estimate the bio-optical parameters through remote sensors, since phytoplankton communities include different species and sizes; which reflect differences in the shape and magnitude of the spectral curve [20]. In this study, the ecological zonation of phytoplankton provinces was characterized based on differences on the spectral absorption shape $\left(a_{p h} n / 440 \mathrm{~nm}\right)$, mainly if we observed anomalous oceanographic interannual changes off Baja California during the summers 2001-02-03.

\section{Materials and Methods}

\subsection{Study Area}

The Baja California Peninsula is located between $24^{\circ} \mathrm{N}-32^{\circ} \mathrm{N}$ and $112^{\circ} \mathrm{W}$ $119^{\circ} \mathrm{W}$, the ocean flows along its west coast what is known as the California 
Current System (SCC), which has an influence on the hydrographic conditions off Baja California (BC). The SCC, includes the California Current (CC) with a depth $\sim 0-300 \mathrm{~m}$ and southward flow with velocity less than $25 \mathrm{~cm} \cdot \mathrm{s}^{-1}[21]$ and the California Countercurrent (CCC) with a coastal circulation and a discontinuous seasonality [22]. The interannual variability of the SCC is related to climatological changes and atmospheric circulation in mid-latitudes, causing anomalies such as swirls, meanders and fronts that influence the pelagic ecosystems off Baja California [23] [24]. The wind forcing it has been considered that the main mechanism that regulates the SCC, and which acts on the CC producing instability of the system during spring-summer that favoring the process of the coastal upwelling's [25].

\subsection{Sampling Strategy}

Three oceanographic cruises were carried out onboard the B/O Francisco de Ulloa: 1) June 26 to July $17,2001,2$ ) July 12 to August 2, 2002, and 3) July 7 to 29 , 2003, within the framework of the Mexican Research California Current (IMECOCAL) Program. We analyzed samples from a total of 91 stations distributed between Ensenada, BC and south of Asunción Bay (Figure 1). Temperature and salinity profiles were constructed using a CTD (SeaBird SBE-911) equipped with a rosette of $5 \mathrm{~L}$ Niskin bottles. Biological and chlorophyll-a (Chl-a) samples were collected at $10 \mathrm{~m}$ depth. The absorption coefficients of the particulate material $\left(a_{p}\right)$ were obtained by filtering $1 \mathrm{~L}$ of sea water in filters GF/F $(25 \mathrm{~nm})$, stored in HistoPrep ${ }^{\circledR}$ capsules and deposited in liquid nitrogen. The concentration of Chl-a was obtained using the fluorometry technique according to [26]. The phytoplankton samples were stored in $250 \mathrm{~mL}$ dark bottles, preserved in formaldehyde (4\% final concentration) and neutralized with sodium borate ( $\mathrm{pH} 7.5$ - 8.0) according to [27].

\subsection{Phytoplankton Light Absorption Coefficients}

To estimate the absorption coefficients, the GF/F filters were analyzed one week after each oceanographic cruise using a Shimadzu UV-2401 PC spectrophotometer with an integrating light sphere. Subsequently, a spectral sweep was carried out between $400-750 \mathrm{~nm}$ with a resolution of $1 \mathrm{~nm}$ and a spectral bandwidth of $2 \mathrm{~nm}$, at a mean scanning speed of $300 \mathrm{~nm} \cdot \mathrm{min}^{-1}$. In the first instance, we obtained the spectral curve of the particulate material $\left(a_{p}\right)$, then the filters were rinsed with methanol for $15 \mathrm{~min}$ following the technique of [28] with a second spectral sweep obtaining the detritus curve $\left(a_{d}\right)$. The difference between both curves allowed obtaining the light absorption coefficient by phytoplankton $\left(a_{p h}\right)$. The normalized spectral shape by phytoplankton $\left(a_{p h} n\right)$ was obtained dividing the $a_{p h}$ between the under area of the curve from 400 to $750 \mathrm{~nm}$ using Equation (1):

$$
a_{p h} n=\frac{a_{p h}(\lambda)\left(\mathrm{m}^{-1}\right)}{\int_{400}^{750} a_{p h}(\lambda)\left(\mathrm{m}^{-1}\right) \delta \lambda(\mathrm{nm})}
$$




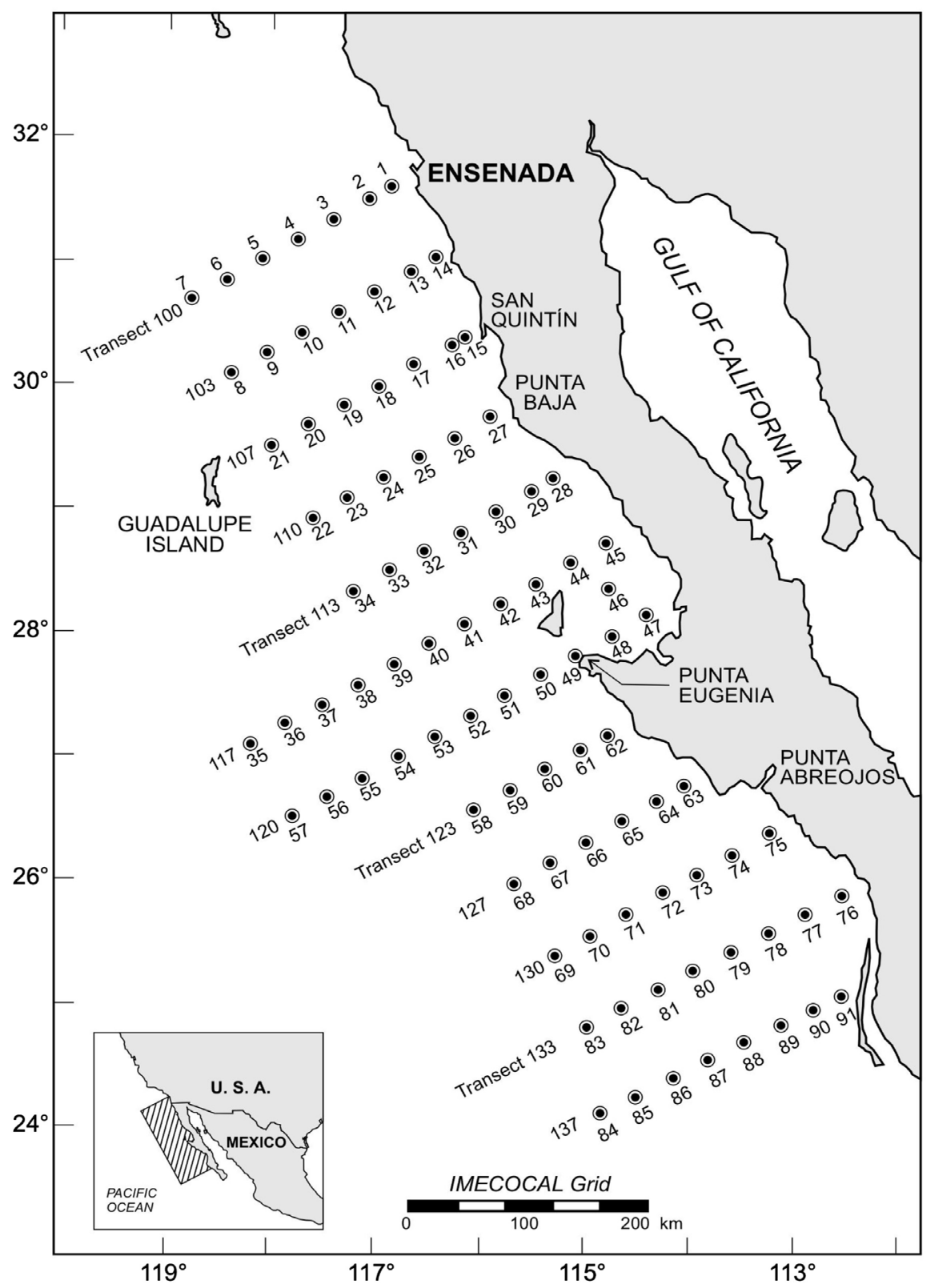

Figure 1. Map of the study area showing a subset of the original CalCOFI grid. Location of the stations sampled during the summer seasons in 2001-02-03 off Baja California. Samples were taken at $10 \mathrm{~m}$ depth.

\subsection{Composition and Biomass of Phytoplankton}

To determine the taxonomic groups of phytoplankton, $50 \mathrm{~mL}$ of seawater were sediment during $24 \mathrm{~h}$ following [29], using an inverted microscope (Carl Zeiss at $160 \times$ and 400x). Nano and microphytoplankton were identified at genus level according to [30] [31] [32]. In this study, only diatoms were measured through an ocular micrometer, because the size is more homogeneity and stable than dinoflagellates and facility the calculator of the biomass. These measurements were converted to biovolume $\left(\mu \mathrm{m}^{3}\right)$ assuming the stoichiometric forms suggested by [33]. The biomass of the population is calculated following Equation (2): 


$$
B_{p}=C_{p} \cdot V_{p} \cdot F_{p}
$$

where $B_{p}$ is the biomass population $\left(\mu \mathrm{g} \mathrm{C} \mathrm{L}^{-1}\right), C_{p}$ cell concentration (cells $\left.\mathrm{L}^{-1}\right), \quad V_{p}$ average cellular bio-volume $\left(\mu \mathrm{m}^{3}\right.$ cells $\left.\mathrm{L}^{-1}\right)$, and $F_{p}$ conversion factor from bio-volume to carbon according to [34]. The genera were sorted and classified hierarchically according to the Niche Amplitude Index [20] [35] following Equation (3). The Bi value indicates the importance of the distribution of any taxon along the stations grid.

$$
B_{i}=\exp \left[-\sum_{j=1}^{K}\left(P_{i j} / R_{j}\right) \ln \left(P_{i j} / R_{j}\right)\right]
$$

where $B_{i}$ is Niche Amplitude Index, $\left(P_{i j} / R_{j}\right)$ is the proportion of the genus $i$ in the sample $j$, and $\left(P_{i j} / R_{j}\right)$ over the sum proportion in each genus.

\subsection{Ecological Zonation of Phytoplankton}

In this study, we considered that the absorption spectral shape $\left(\frac{a_{p h} n}{a_{p h} n 440 \mathrm{~nm}}\right)$ is the fingerprint that reflects the photosynthetic pigments of phytoplankton and with a posteriori analyses us make up separated and grouped in similar spectral curves as the most representative phytoplankton composition in each station. For this reason, the spectral curves were characterized by the slope differentiation method (440 - $550 \mathrm{~nm})$, as reported by [20].

\section{Results}

\subsection{Coefficient of Light Absorption by Phytoplankton}

A total of 117 absorption spectral curves were generated, which were grouped into four average spectral shapes (Figure 2) that represent the ecological zonation
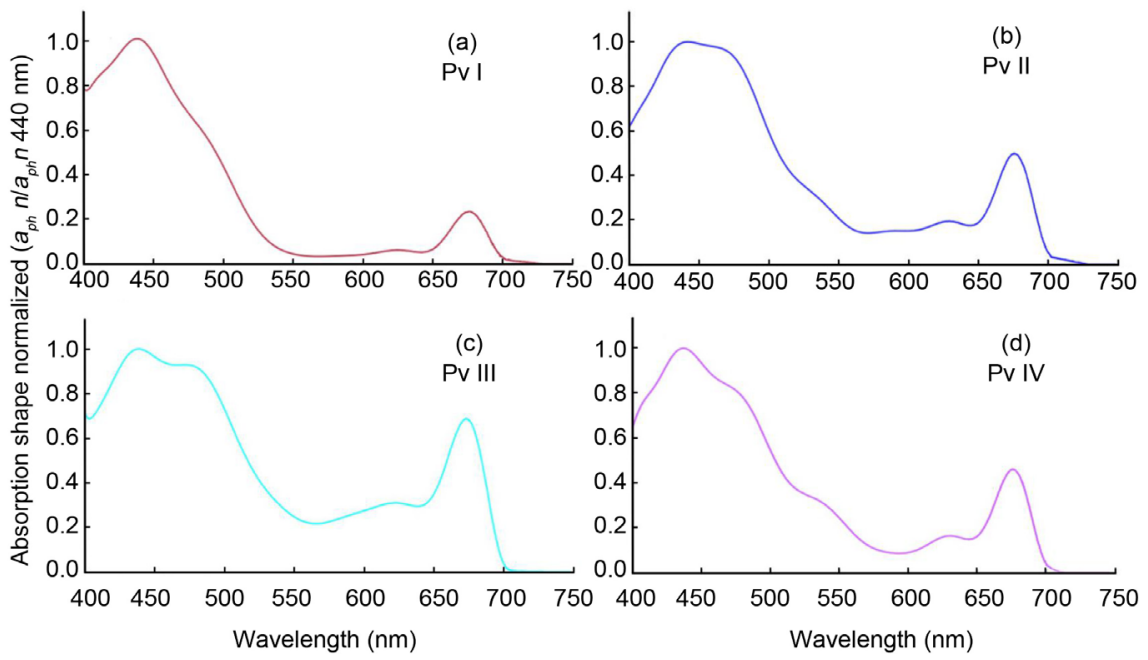

Figure 2. Averages of the normalized absorption shapes $\left(a_{p h} n / a_{p h} n 440 \mathrm{~nm}\right)$ during the summer season for each ecological zonation of phytoplankton provinces (Pv). (a) Pv I (102 spectral curves); (b) Pv II (13 spectral curves); (c) Pv III (1 spectral curve); and (d) Pv IV (1 spectral curve). The samples were taken at $10 \mathrm{~m}$ depth. 
of phytoplankton denominated provinces (Pv I, Pv II, Pv III, Pv IV). For 200120 stations were analyzed and grouped into two different spectral shapes: Pv I with 17 stations and Pv II with 3. In contrast the 2002 grouped 59 stations in 3 provinces: Pv I with 51, Pv II with 7, and Pv III with 1 station. While in 20033 provinces were defined: Pv I with 34 stations, Pv II with 3, and Pv IV with 1 station (Figure 3). In general, the Pv I was reflected in 102 spectral curves, the Pv II in 13, the Pv III and Pv IV in 1 spectral curve. The spatial distribution of the Pv I during 2001 covered from Ensenada to south of Asunción Bay, while the Pv II was located in Vizcaíno Bay (Figure 4(a)). Unlike 2002 and 2003, where Pv I comprised a large part of the study area, while Pv II, Pv III and Pv IV were located in small areas (Figure 4(b) and Figure 4(c)).

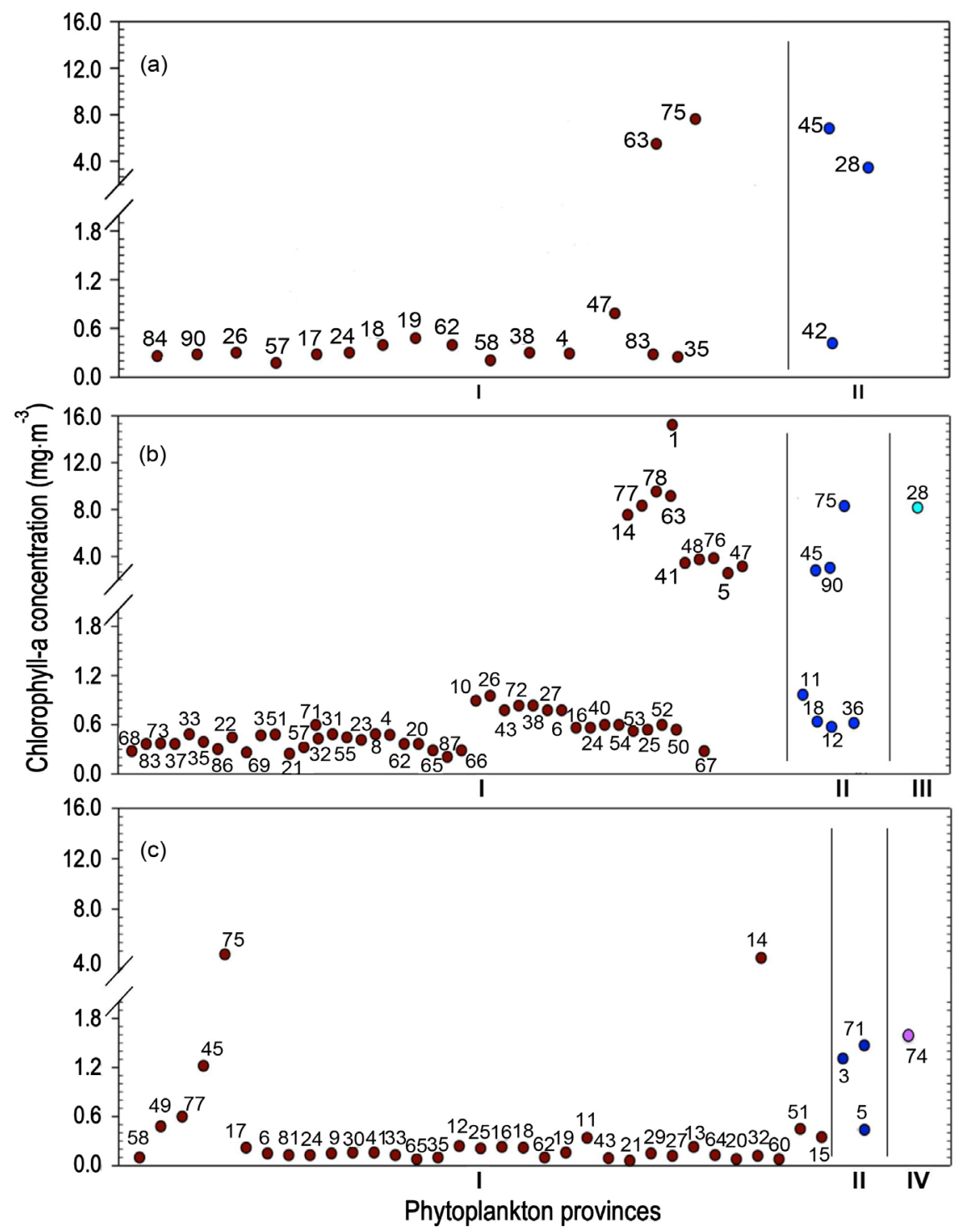

Figure 3. Ecological zonation of phytoplankton provinces $(\mathrm{Pv})$ for each summer season (2001-02-03). The ordinate axe is chlorophyll-a concentration $\left(\mathrm{mg} \cdot \mathrm{m}^{-3}\right)$, and abscissa axes correspond to each phytoplankton provinces off Baja California. The samples were taken at $10 \mathrm{~m}$ depth. 


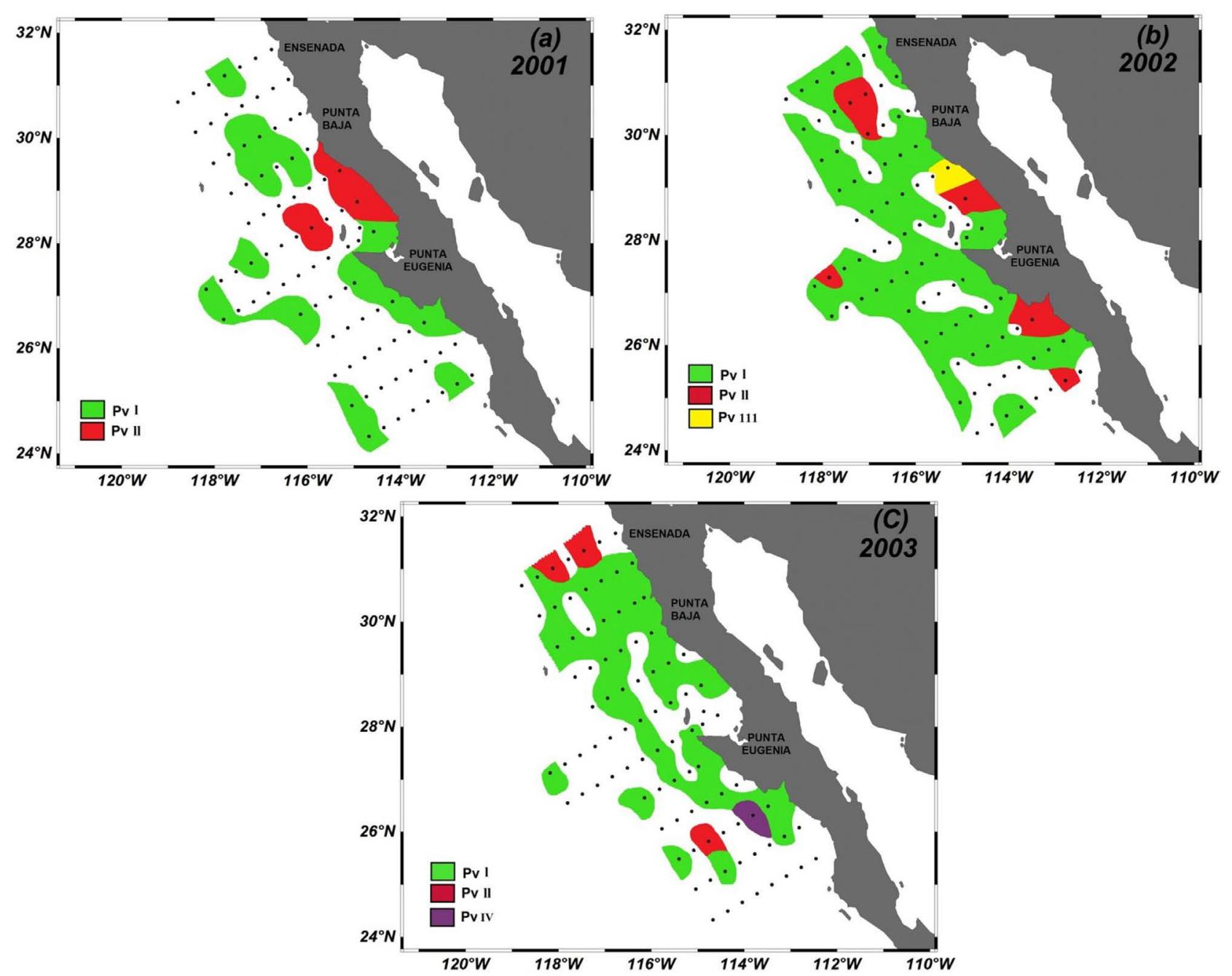

Figure 4. Spatial-temporal distribution of the ecological zonation of phytoplankton provinces off Baja California during summer season according to the normalized absorption shapes (2001-02-03). The green color (Pv I), red color (Pv II), yellow color (Pv III) and purple color ( $\mathrm{Pv}$ IV). The samples were taken at $10 \mathrm{~m}$ depth.

\subsection{Spatial and Temporal Variability of Phytoplankton}

In general, during the summer of 2001 the spatial distribution of phytoplankton presented a high abundance of cells towards the coast stations, with an increase of $3.96 \times 10^{5} \mathrm{~L}^{-1}$ cells (Figure $5(\mathrm{a})$ ). The main taxonomic group consisted of diatoms with $2.9-3.9 \times 10^{5}$ cells $\mathrm{L}^{-1}$ (63, 74 y 75 stations) at South of Punta Abreojos; while, dinoflagellates contributed to $1.87 \times 10^{4} \mathrm{~L}^{-1}$ cells (Figure 6(a)), unlike the silicoflagellates that showed little abundance. However, during summer 2002 the abundance of phytoplankton decreased 50\% compared to 2001 (Figure 5(b)), revealing traces of the diatom group on lines 100 and 103 near the coast $\left(1.26-1.72 \times 10^{5}\right.$ cells L $\left.\mathrm{L}^{-1}\right)$ and South of Asunción Bay on lines 127 and 130 (1.6 - $1.9 \times 10^{4}$ cells $\left.\mathrm{L}^{-1}\right)$; while the dinoflagellates showed abundances of $1.9 \times$ $10^{4} \mathrm{~L}^{-1}$ cells south of Punta Abreojos (Figure 6(a)). Finally, diatoms abundance increased during summer $2003\left(2.39 \times 10^{5}\right.$ cells $\left.\mathrm{L}^{-1}\right)$ towards the oceanic region off Ensenada and San Quintín (Figure 5(c) and Figure 6(a)). 


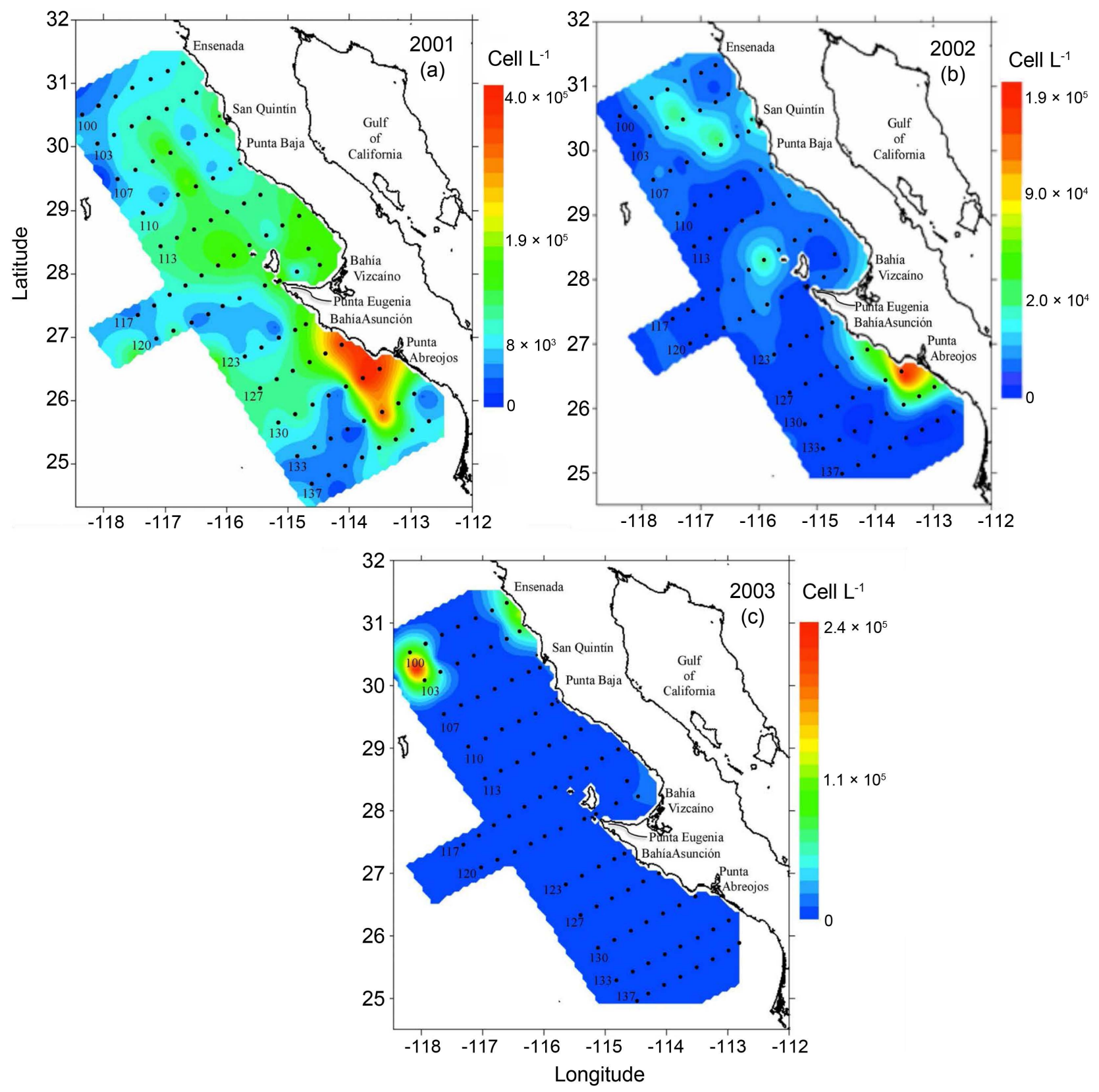

Figure 5. Spatial-temporal distribution of total phytoplankton (cells $\mathrm{L}^{-1}$ ) at $10 \mathrm{~m}$ depth during IMECOCAL cruises summer season (2001-02-03).

\subsection{Structure of the Phytoplankton Community}

In hierarchical order $(B i)$, a total of 29 genera of phytoplankton were reported corresponding to the nano-microphytoplankton group $(>5 \mu \mathrm{m})$ during summer 2001-02-03, out of which 16 correspond to diatoms including: Nitzschia, Coscinodiscus, Rhizosolenia, Navicula, Chaetoceros, Thalassionema, Cocconeis, Pseudoeunotia, Hemiaulus, and Eucampia; while 13 correspond to dinoflagellates: Gymnodinium, Ceratium, Gyrodinium, Oxytoxum, Prorocentrum, Gonyaulax, Protoperidinium, Dinophysis, Podolampas, and Peridinium (Table 1). Its percentage contribution by taxonomic groups in relation to each province 

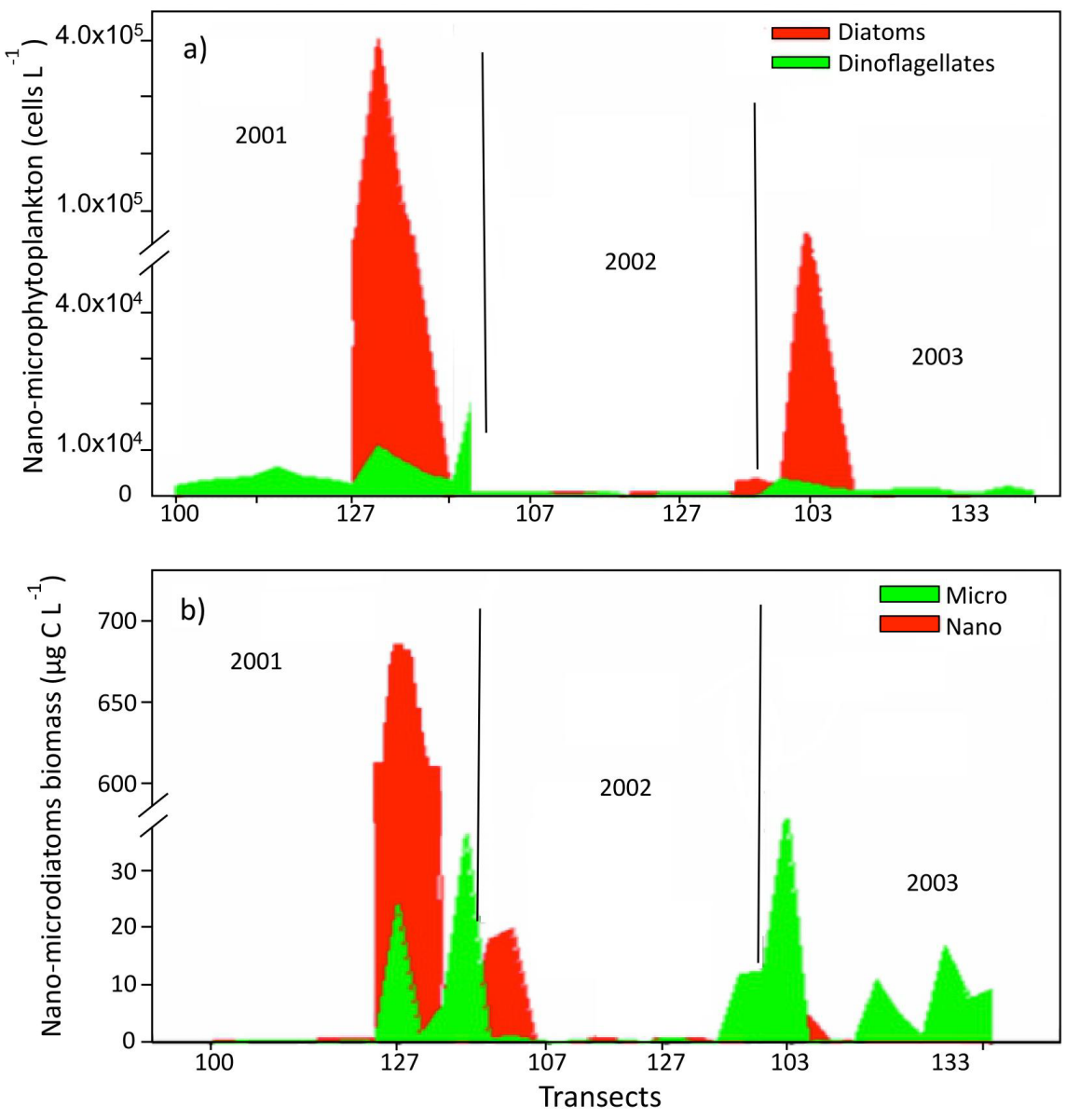

Figure 6. (a) Contribution of each phytoplankton group; diatoms and dinoflagellates (cells $\left.\mathrm{L}^{-1}\right)$; (b) Size-fractioned biomass $\left(\mu \mathrm{g} \mathrm{C} \mathrm{L}^{-1}\right)$ at $10 \mathrm{~m}$ depth during summer season (2001-02-03).

with spectral shape were: Pv I, showed $89 \%$ contribution of diatoms compared to the dinoflagellates that contributed $11 \%$. Pv II, contributed with $48 \%$ of dinoflagellates and 52\%; diatoms while Pv III and Pv IV presented a contribution of $72 \%$ and $88 \%$ of dinoflagellates and little presence of diatoms with $28 \%$ and $12 \%$, respectively.

\subsection{Biomass of Phytoplankton (Nano-Microdiatoms)}

In summer 2001, the highest phytoplankton biomass occurred at south of Asunción Bay (Transects 127 and 130) where the nano-diatoms (Nitzschia, Chaetoceros, Thalassionema, and Navicula) showed values between 688 and $186 \mu \mathrm{g} \mathrm{C}$ $\mathrm{L}^{-1}$, respectively. Micro-diatoms (Thalassiosira, Rhizosolenia, and Coscinodiscus) presented values $<24 \mu \mathrm{g} \mathrm{C} \mathrm{L}{ }^{-1}$, in transects 127 and 137 respectively (Figure 6(b)). In general, during 2002 a decrease in biomass was observed, except between Ensenada and San Quintín Bay (Transects 100 and 103) where the nano-diatoms reached values of 17.8 and $19.6 \mu \mathrm{g} \mathrm{C} \mathrm{L} \mathrm{L}^{-1}$ respectively; while the micro-diatoms showed greater presence in the transect 137 with $11.8 \mu \mathrm{g} \mathrm{C} \mathrm{L^{-1 }}$ (Figure 6(b)). Finally, during 2003 the micro-diatoms dominated in two main 


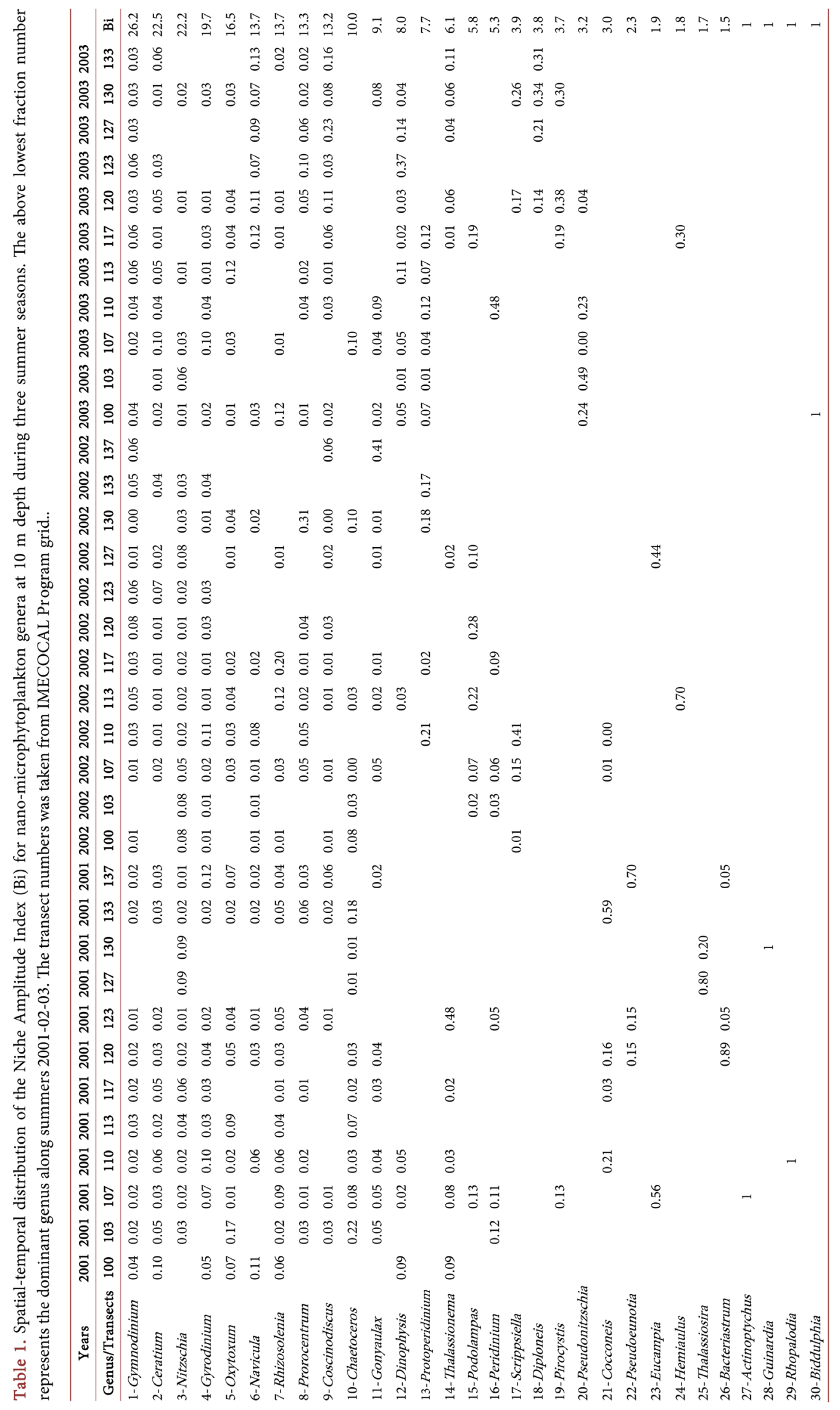


areas: 1) located between Ensenada and San Quintín with 12.3 and $40.5 \mu \mathrm{g} \mathrm{C} \mathrm{L} \mathrm{L}^{-1}$ respectively, and 2) South of Punta Eugenia with $16.6 \mu \mathrm{g} \mathrm{C} \mathrm{L}^{-1}$ (Transect 127). The rest of the study area showed intervals between $0.18-9 \mu \mathrm{g} \mathrm{L} \mathrm{L}^{-1}$. (Figure 6(b)).

\section{Discussion}

The physical and biological oceanographic conditions in the CC off Baja California (BC) during 2001 period have been widely characterized by [8] [12], where these authors emphasize that the presence of upwelling, processes of turbulence and/or mixing cause a rise of nutrients towards the surface, favoring the increase of phytoplankton cells with a greater proportion of diatoms. Likewise, they also suggested that NW BC region was related to the presence of the event called "La Niña". During our 2001 study, the highest abundances of phytoplankton were detected in coastal stations located between Asunción Bay and Punta Abreojos, where the nano-diatoms group $(5-20 \mu \mathrm{m})$ dominated and presented an average biomass of $300 \mu \mathrm{g} \mathrm{C} \mathrm{L}{ }^{-1}$. In hierarchical order organisms most representative were: Gymnodinium, Ceratium, Gyrodinium, Oxytoxum, Nitzschia, Coscinodiscus, Rhizosolenia, Navicula and Chaetoceros. These results were consistent with the conceptual framework proposed in the Margalef's Mandala [2]. In this Mandala life-forms of phytoplankton are placed in an ecological space defined by nutrients and turbulence, where the diatoms are associated with rich and turbulent waters, while in the opposite corner of the Mandala, small and swimming cells are related to calm and poor waters as well as dinoflagellates developed in calm waters and little nutrients; so we deduce in this study, a community in stage called post-emergence with an increase towards the group of dinoflagellates, as shown in Table 1.

Authors such as [10] [12] used climate indices such as the ENSO (El Niño-Southern Oscillation), MEI (Multivariate El Niño [13]), and PDO (Pacific Decadal Oscillation [14]) to determine oceanographic differences that occurred between the summers 2002-03 in relation to the 2001 to the south of the CC off Baja California, reaching the conclusion that the years 2002-03 showed evidence of the El Niño event "weak" in relation to those observed in 1982-83 and 1997-98 considered as a strong oceanographic anomaly. In this sense, our results about abundances and biomass phytoplankton in the El Niño years (Figure 5(b) and Figure 5(c) and Figure 6(b)), showed characteristics of an oligotrophic zone throughout the study area, except in the oceanic stations of the northern region (lines 100 and 103) and southern region (line 130) that showed evidence of coastal zones. This was possibly due to local oceanographic processes typical of the area, where meandering and eddies occur, as reported by [36] [37] when using satellite images. On the other hand, the group of dinoflagellates showed an increase during 2002-03 strengthening the idea of a clear decrease of the diatom group when detecting the presence El Niño event, as observed in Figure 6(a) and Figure 7 in relation to the decadal interannual variability of the multivariate ENSO index of the IMECOCAL and CalCOFI (California Cooperative Oceanic 


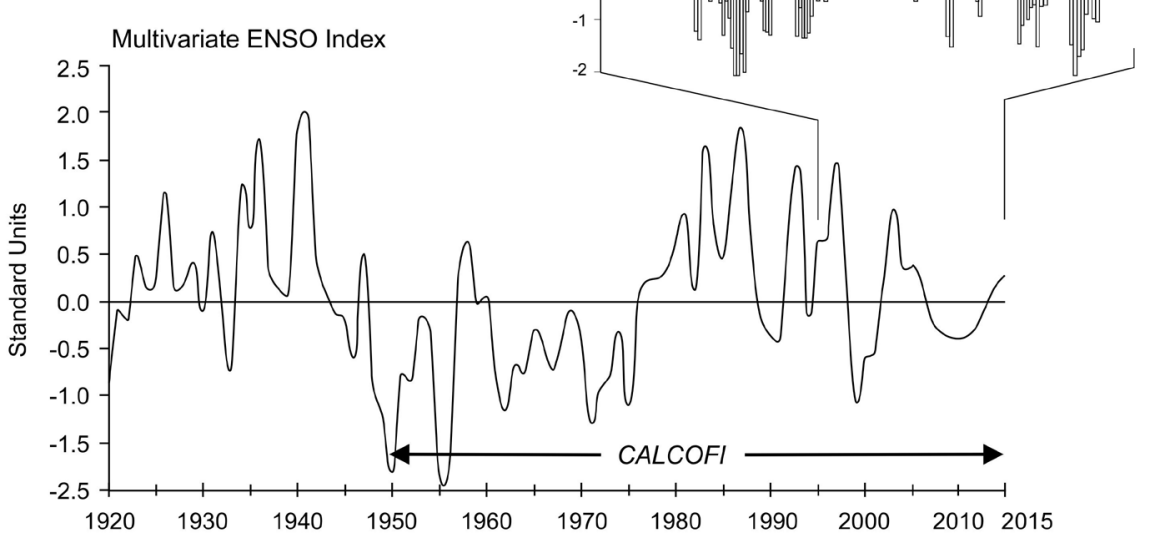

Figure 7. The interannual to interdecadal variability of the multivariate ENSO index of the IMECOCAL and CalCOFI Programmes in the region of the California current for the period 1920-2014 was taken from [41].

Fisheries Investigations) programs.

In order to understand that environmental and biological factors causing variability of the spectral shape in relation to phytoplankton community structure, it was necessary to determine the inherent optical properties of water [38]. Oceanographic studies related to hydrological optics have reported that light absorption coefficients have two types of variability: magnitude and shape [9] [39] [40], arguing these authors that the shape is due to pigments composition. In contrast, the magnitude is directly related to pigments concentration; as it was observed in Figure 3, where the phytoplankton provinces are independent of the Chl- a concentration.

The subjective visual and/or statistical differentiation of the spectral slope, particularly through the shoulder between $440-550 \mathrm{~nm}$, provides a relationship between the shape and structure of the community, as observed in Pv I where the presence of diatoms it was $89 \%$ and $11 \%$ dinoflagellates. Therefore, we determined that a greater slope is characteristic of the diatom group, very similar results were reported in Baja California during spring 2008 [41]. However, Pv III in Figure 2(c) showed opposite characteristics to Pv I, where the percentage of dinoflagellates was greater in $72 \%$ than the diatoms group (28\%). It is important to note that Pv III was only found at station 28 during summer 2002 south of Punta Baja, where it has traditionally been considered as a region of upwelling events. The Pv IV in Figure 2(d) was related to an increase of dinoflagellate abundances with $88 \%$ in relation to $12 \%$ of the diatoms group; similarly, a lower slope with wavy tendencies is observed, this due to the variability of pigments in the sample of particulate material in suspension. Therefore, it is concluded that the spectral curves of $a_{p h}$, are the footprint of a taxonomic community captured 
in GF/F filters with porosity $\sim 0.7 \mu \mathrm{m}$, which considers the presence of picoplankton (not analyzed in this study), as well as the nano-microphytoplankton reported in this work.

\section{Acknowledgements}

A crew and commander of B/O Francisco de Ulloa for his experience in offshore. To technicians and students in the ocean collection of samples and support in the laboratory analysis: especially to Martin De la Cruz, Wendy Pérez Leal, and Francisco Ponce for improved the figures. The research was carried out under the project SEMARNAT-CONACyT \# 23804 of the IMECOCAL. Dr. Gilberto Gaxíola-Castro leader in this program.

\section{Conflicts of Interest}

The authors declare no conflicts of interest regarding the publication of this paper.

\section{References}

[1] Stocker, T.F., Qin, D., Plattner, G.-K., Tignor, M., Allen, S.K., Boschung, J., Nauels, A., Xia, Y., Bex, V. and Midgley, P.M. (2013) Climate Change 2013: The Physical Science Basis. Contribution of Working Group I to the Fifth Assessment Report of the Intergovernmental Panel on Climate Change. Cambridge University Press, Cambridge, 1535.

[2] Crisholm, S.W. (2014) Margalef s Mandala, Prochlorococcus, and geoengineering. Contributions to Science Open Access, 10, 7-15.

[3] Le Quéré, C., Harrison, S.P., Colin-Prentice, I., Buitenhuis, E.T., Aumont, O., Bopp, L., Claustre, H., Cotrim Da Cunha, L., Geider, R., Giraud, X., Klaas, C., Kohfel, K.E., Legendre, L., Manizza, M., Platt, T., Rivkin, R.B., Sathyendranath, S., Uitz, J., Watson, A.J. and Wolf-Gladrow, D. (2005) Ecosystem Dynamics Based on Plankton Functional Types for Global Ocean Biogeochemistry Models. Global Change Biology, 11, 2016-2040. https://doi.org/10.1111/j.1365-2486.2005.1004.x

[4] Bracher, A., Bouman, H.A., Brewin, R.J.W., Bricaud, A., Brotas, V., Ciotti, A.M., Clementson, L., Devred, E., Di Cicco, A., Dutkiewicz, S., Hardman-Mountford, N.J., Hickman, A.E., Hieronymi, M., Hirata, T., Losa, S.N., Mouw, C.B., Organelli, E., Raitsos, D.E., Uitz, J., Vogt, M. and Wolanin, A. (2017) Obtaining Phytoplankton Diversity from Ocean Color: A Scientific Roadmap for Future Development. Frontiers Marine Science, 4, 55. https://doi.org/10.3389/fmars.2017.00055

[5] Yuan, C. and Yamagata, T. (2014) California Niño/Niña. Science Report, 4, Article No. 4801. https://doi.org/10.1038/srep04801

[6] Espinosa-Carreón, L.T., Valdez-Holguín, J.E. (2007) Variabilidad interanual de clorofila en el Golfo de California. Ecologia Aplicada, 6, 81-92.

https://doi.org/10.21704/rea.v6i1-2.344

[7] Dajoz, R. (2002) Tratado de Ecología. 2nd Edition, Mundi-Prensa, Madrid, 600.

[8] Durazo, R. and Baumgartner, T. (2002) Evolution of Oceanographic Conditions off Baja California: 1997-1999. Progress in Oceanography, 54, 7-31. https://doi.org/10.1016/S0079-6611(02)00041-1

[9] Millán-Núñez, E., Sieracki, M.E., Millán-Núñez, R., Lara-Lara, J.R., Gaxiola-Castro, 
G. and Trees, C.C. (2004). Specific Absorption Coefficient and Phytoplankton Biomass in the Southern Region of the California Current. Deep Sea Research Part II: Topical Studies in Oceanography, 51, 817-826. https://doi.org/10.1016/j.dsr2.2004.05.023

[10] Schwing, F.B., Bograd, S.J., Collins, C.A., Gaxiola-Castro, G., García, J., Goericke, R., Gómez-Valdés, J., Huyer, A., Hyrenbach, K.D., Kosro, P.M., Lavaniegos, B.E., Lynn, R.J., Mantyla, A.W., Ohman, M.D., Peterson, W.T., Smith, R.L., Sydeman, W.J., Venrick, E. and Wheeler, P.A. (2002) The State of the California Current, 2001-2002: Will the California Current Keep Its Cool, or Is El Niño Looming? California Cooperative Oceanic Fisheries Investigations Report, 43, 31-73.

[11] Millán-Núñez, E. and Millán-Núñez, R. (2010) Specific Absorption Coefficient and Phytoplankton Community Structure in the Southern Region of the California Current during January 2002. Journal of Oceanography, 66, 719-730. https://doi.org/10.1007/s10872-010-0059-Z

[12] Gaxiola-Castro, G., Durazo, R., Lavaniegos, B., De La Cruz-Orozco, M.E., Millan-Nuñez, E., Soto-Mardones, L. and Cepeda-Morales, J. (2008) Pelagic Ecosystem Response to Interannual Variability off Baja California. Ciencias Marinas, 34, 263-270. https://doi.org/10.7773/cm.v34i2.1413

[13] Wolter, K. and Timlin, M.S. (1998). Measuring the Strength of ENSO Events-How Does 1997/98 Rank? Weather, 53, 315-324. https://doi.org/10.1002/j.1477-8696.1998.tb06408.x

[14] Mantua, N.J.S., Hare, R., Zhang, Y., Wallace, J.M. and Francis, R.C. (1997) A Pacific Decadal Climate Oscillation with Impacts on Salmon Productions. Bulletin American Meteorological Society, 78, 1069-1079. https://doi.org/10.1175/1520-0477(1997)078<1069:APICOW>2.0.CO;2

[15] IOCCG (2000) Remote Sensing of Ocean Colour in Coastal, and Other Optically-Complex, Waters. In: Sathyendranath, S., Ed., Reports of the International Ocean-Colour Coordinating Group, IOCCG, Dartmouth, 1-140.

[16] Costa-Goela, P., Icely, J., Cristina, S., Newton, A., Moore, G. and Cordeiro, C. (2013) Specific Absorption Coefficient of Phytoplankton off the Southwest Coast of the Iberian Peninsula: A Contribution to Algorithm Development for Ocean Colour Remote Sensing. Continental Shelf Research, 52, 119-132. https://doi.org/10.1016/j.csr.2012.11.009

[17] Kirk, J.T.O. and Tyler, P.A. (1986) The Spectral Absorption and Scattering Properties of Dissolved and Particulate Components in Relation to the Underwater Light Field of Some Tropical Australian Fresh-Waters. Freshwater Biology, 16, 573-583. https://doi.org/10.1111/j.1365-2427.1986.tb01001.x

[18] Cleveland, J.S. (1995) Regional Models for Phytoplankton Absorption as a Function of Chlorophyll a Concentration. Journal of Geophysical Research: Oceans, 100, 13333-13344. https://doi.org/10.1029/95JC00532

[19] Sosa-Àvalos, R., Millán-Núñez, E., Quijano-Scheggia, S.I., Lara-Lara, J.R. and Silva-Iñiguez, L. (2015) Variability of the Absorption Coefficient for Phytoplankton Influence of Red Tide in Manzanillo and Santiago Bays, Mexico. Revista de Biología Marina y Oceanografía, 50, 427-438. https://doi.org/10.4067/S0718-19572015000400003

[20] Millán-Nuñez, E. and Macías Carballo, M. (2014) Phytogeography Associated at Spectral Absorption Shapes in the Southern Region of the California Current. California Cooperative Oceanic Fisheries Investigations Report, 550, 183-196.

[21] Gómez-Ocampo, E., Gaxiola-Castro, G., Durazo, R. and Beier, E. (2018) Effects of 
the 2013-2016 Warm Anomalies on the California Current Phytoplankton. Deep Sea Research Part II: Tropical Studies in Oceanography, 151, 64-76. https://doi.org/10.1016/j.dsr2.2017.01.005

[22] Sverdrup, H.V., Johnson, M.W. and Fleming, R.H. (1942) The Oceans: Their Physics, Chemistry and General Biology. Prentice-Hall, Inc., New York, 1087.

[23] Durazo, R., Gaxiola-Castro, G., Lavaniegos, B., Castro-Valdez, R., Gómez-Valdez, J. and Mascarenhas, A. (2005) Oceanographic Conditions West of the Baja California coast, 2002-2203: A Weak El Niño and Subartic Water Enhancement. Ciencias Marinas, 31, 537-552. https://doi.org/10.7773/cm.v31i3.43

[24] Checkley, D.M. and Barth, J.A. (2009) Patterns and Processes in the California Current System. Progress in Oceanography, 83, 49-64.

https://doi.org/10.1016/j.pocean.2009.07.028

[25] Chhak, K. and Di Lorenzo, D. (2007) Decadal Variations in the California Current Upwelling Cells. Geophysical Research Letters, 34, 1-6. https://doi.org/10.1029/2007GL030203

[26] Holm-Hansen, O., Lorenzen, C., Holmes, R. and Strickland, J. (1965) Fluorometric determination of Chlorophyll. Journal of Marine Science, 30, 3-15. https://doi.org/10.1093/icesjms/30.1.3

[27] Throndsen, J. (1978) Preservation and Storage. In: Sournia, A., Ed., Phytoplankton Manual, UNESCO, Paris.

[28] Kishino, M., Takahashi, M., Okami, N. and Ichimura, S. (1985) Estimation of the Spectral Absorption Coefficients of Phytoplankton in the Sea. ICES Journal of Marine Science, 37, 634-642.

[29] Utermöhl, H. (1958) Zur vervollkommnung der quantitativen phytoplankton methodik. Internationale Vereinigung für Theoretische und Angewandte Limnologie: Mitteilungen, 9, 1-38. https://doi.org/10.1080/05384680.1958.11904091

[30] Licea, S., Moreno, J.L., Santoyo, H. and Figueroa, G. (1996) Dinoflageladas del Golfo de California. Universidad Autónoma de Baja California Sur, Baja California Sur.

[31] Moreno, J.L., Licea, S. and Santoyo, H. (1997) Diatomeas del Golfo de California. Universidad Autónoma de Baja California Sur, Baja California Sur.

[32] Tomas, C.S. (1997) Identifying Marine Phytoplankton. Academic Press, Cambridge, MA.

[33] Edler, L. (1979) Recomendations for Marine Biological Studies in the Baltic Sea. Phytoplankton and Chlorophyll. Baltic Marine Biology, 5, 1-38.

[34] Verity, P.G., Robertson, C.Y., Tronzo, C.R., Andrews, M.G., Nelson, J.R. and Sieracki, M. (1992) Relationships between Cell Volumen and the Carbon and Nitrogen Content of Marine Photosynthetic Nanoplankton. Limnology \& Oceanography, 37, 1434-1446. https://doi.org/10.4319/lo.1992.37.7.1434

[35] Levins, R. (1978) Evolution in Changing Environments. Princeton University Press, Princenton.

[36] Sánchez-Pérez, E.D. (2008) Caracterización de la comunidad de fitoplancton a partir de la forma espectral de absorción frente a Baja California: Veranos 2002-2003. Master Dissertation, Universidad Autónoma de Baja California, Mexicali.

[37] Goericke, R., Venrick, E., Mantyla, A., Bograd, S., Schwing, F.B., Huyer, A., Smith, R.L., Wheeler, P.A., Hooff, R., Peterson, W.T., Gaxiola-Castro, G., Gómez-Valdez, J., Lavaniegos, B.E., Hyrenbach, K.D. and Sydeman, W.J. (2004) The State of the California Current, 2003-2004: A Rare "Normal" Year. California Cooperative Oceanic Fisheries Investigations Report, 45, 27-59. 
[38] Preisendorfer, R.W. (1961) Application of Radioactive Transfer Theory to Light Measurements in the Sea. International Union of Geophysics and International Association of Oceanography, 10, 83-91.

[39] Morel, A. and Bricaud, A. (1981) Theoretical Results Concerning Light Absorption in a Discrete Medium, and Application to Specific Absorption of Phytoplankton. Deep Sea Research, 28, 1375-1393. https://doi.org/10.1016/0198-0149(81)90039-X

[40] Sathyendranath, S., Lazzara, L. and Prieur, L. (1987) Variations in the Spectral Values of Specific Absorption of Phytoplankton. Limnology \& Oceanography, 32, 403-415. https://doi.org/10.4319/lo.1987.32.2.0403

[41] Miranda-Álvarez, A.C., Millán-Núñez, E. (2016) Phytoplankton Oceanographic Characterization during El Niño 2004 Event in the Northwest Region of Baja California, México. Biology Science, 4, 61-81. 